\title{
SOSIALISASI PEMILU KEPADA PEMUDA GUNA MENCIPTAKAN PEMUDA YANG SADAR PEMILU DI KOTA BANJARMASIN
}

\author{
Muhammad Erfa Redhani ${ }^{1}$, Muhammad Syahrial Fitri ${ }^{2}$, Afif Khalid ${ }^{2}$, dan Hanafi ${ }^{2}$ \\ ${ }^{1}$ Fakultas Hukum, Universitas Lambung Mangkurat \\ ${ }^{2}$ Fakultas Hukum, Universitas Islam Kalimantan \\ E-mail : erfa.unlam@gmail.com
}

\begin{abstract}
ABSTRAK
Tujuan dilaksanakannya kegiatan pengabdian ini adalah untuk meningkatkan pemahaman pemilih pemula tentang pemilihan umum di kota Banjarmasin dan untuk meningkatkan partisipasi pemilih pemula pada pemilihan umum di Kota Banjarmasin khususnya yang tergabung dalam Kesatuan Aksi Mahasiswa Muslim Indonesia. Metode yang digunakan dalam kegiatan ini adalah dengan rangkaian tahapan yang disusun secara sistematis yaitu pertama dengan melakukan obeservasi lapangan dan pendataan peserta, pembuatan materi dan bahan lainnya, pembuatan konsep sosialisasi dan pelatihan, pelaksanaan sosialisasi dan pelatihan, membentuk gerakan pemuda sadar pemilu, dan terakhir adalah membuat laporan akhir dan artikel. Dari kegiatan ini hasil atau kesimpulannya adalah dari semua rancangan kegiatan yang tercantum dalam proposal kegiatan telah dapat dilaksanakan, meskipun terdapat beberapa kendala namun telah dapat diatasi. Antusiasme mahasiswa yang tergabung dalam Kesatuan Mahasiswa Muslim Indonesia sangat bagus terutama dalam komitmennya mengawal pelaksanaan pemilu 2019 dan turut berpartisipasi dalam menggunakan hak pilihnya. KAMMI terdaftar resmi sebagai pemantau pemilu di Badan Pengawas Pemilihan Umum (Bawaslu) sehingga dapat secara langsung berkontribusi mengawal pelaksanaan pemilu.
\end{abstract}

Kata Kunci: Sosialisasi, pemilu, pemilih pemula

\section{PENDAHULUAN}

Salah satu elemen penting dalam pelaksanaan pemilu adalah partisipasi warga yang memiliki hak pilih untuk menggunakan haknya secara baik tanpa paksaan dan unsur negatif lainnya. Partisipasi memilih menjadi salah satu kebutuhan agar keberlanjutan demokrasi dan sistem politik tidak mengalami hambatan. Pemilu sebagai instrumen utama demokrasi merupakan salah satu instrumen yang menjembatani suara rakyat sebagai pemilik kedaulatan untuk memberikan mandat kepada seseorang sebagai wakil rakyat atau sebagai penguasa yang akan duduk dalam pemerintahan. Tidaklah heran isu tinggi rendahnya angka partisipasi berkaitan dengan tingkat legitimasi dan kepercayaan warga kepada wakil mereka atau orang yang diberi mandat untuk menjalankan pemerintahan dan mengeluarkan kebijakan. Sebagai salah satu bagian dari keberlanjutan demokrasi, tingkat partisipasi pemilih juga akan berdampak 
pada siapa yang akan memenangkan pemilihan umum dan mengatur kehidupan banyak orang. Oleh karena itu, sebagian negara-negara yang menganut demokrasi, termasuk Indonesia, menjadikan partisipasi sebagai salah satu agenda yang tidak dapat dikesampingkan dalam proses pemilu khususnya dalam hal hadir atau tidaknya warga negara untuk memilih.

Salah satu elemen masyarakat yang besar pengaruhnya dalam partisipasi pemilu adalah elemen pemuda. Pemuda sebagai generasi penerus bangsa idealnya mempunyai peran dalam kemajuan bangsa. Pentingya peran generasi muda, didasari atau tidak, pemuda sejatinya memiliki peran dan fungsi yang strategis dalam akselerasi pembangunan termasuk pula dalam kehidupan berbangsa dan bernegara. Baik buruknya suatu negara dilihat dari kualitas pemudanya, karena generasi muda adalah penerus dan pewaris bangsa dan negara. Pemuda berperan aktif sebagai agen perubahan. Sebagai agen perubahan diwujudkan dengan dengan keterlibatan atau berpartisipasinya pemuda dalam pemilu.

Pemilih pemula merupakan subjek dan objek dalam kegiatan politik termasuk di dalamnya adanya kegiatan pemilihan umum. Pemilih pemula sebagai objek dalam kegiatan politik, yaitu mereka yang masih memerlukan pembinaan dalam orientasi kearah pertumbuhan potensi dan kemampuan dalam bidang politik. Mereka sebagai penerus bangsa perlu memiliki wawasan dan pengetahuan dalam bidang politik termasuk kegiatan pemilihan umum. Disinilah peran pemuda diperlukan, peran pemuda sangat sentral mengingat pemuda sudah pernah menggunakan hak pilih, memiliki wawasan dalam bidang politik, memiliki jangkaun politik yang luas, tahu untuk menentukan ke mana mereka harus memilih. Selain itu, pengalaman dan pengetahuan dalam soal politik praktis, membuat pemuda berpikir lebih rasional.

Salah satu elemen pemuda di Kota Banjarmasin adalah Kesatuan Aksi Mahasiswa Muslim Indonesia. KAMMI adalah organisasi ekstra kampus yang menghimpun mahasiswa muslim seluruh Indonesia secara lintas sektoral, suku, ras dan golongan (https://www.kammi.or.id/, diakses pada 28 September 2018). Di Kota Banjarmasin, KAMMI memiliki anggota yang berlatarbelakang mahasiswa dan otomatis adalah pemilih 
pemula sebanyak ratusan orang yang tersebar diberbagai kampus di Banjarmasin.

Oleh karena berasal dari berbagai kampus di Kota Banjarmasin, KAMMI memiliki anggota yang tidak saja berlatarbelakang pendidikan sosial, politik dan hukum yang notabane lebih melek politik. Tetapi juga berlatarbelakang eksak yang tentu membutuhkan pembelajaran sosial, politik dan hukum khususnya mengenai pemilihan umum.

\section{KHALAYAK SASARAN}

Masyarakat yang menjadi sasaran dalam Pengabdian Masyarakat ini adalah para pemuda yang tergabung dalam Kesatuan Aksi Mahasiswa Muslim Indonesia Kota Banjarmasin yang terdiri dari

Universitas Lambung Mangkurat : 50 Orang

Universitas Islam Negeri Antasari : 20 Orang

Universitas Islam Kalimantan MAAB : 20 Orang

Universitas Muhammadiyah

Banjarmasin : 20 Orang

\section{METODE}

Metode pengembangan yang akan dilaksanakan merupakan sebuah rangkaian tahapan yang disusun secara sistematis, berikut adalah gambaran flowmap yang akan berjalan :

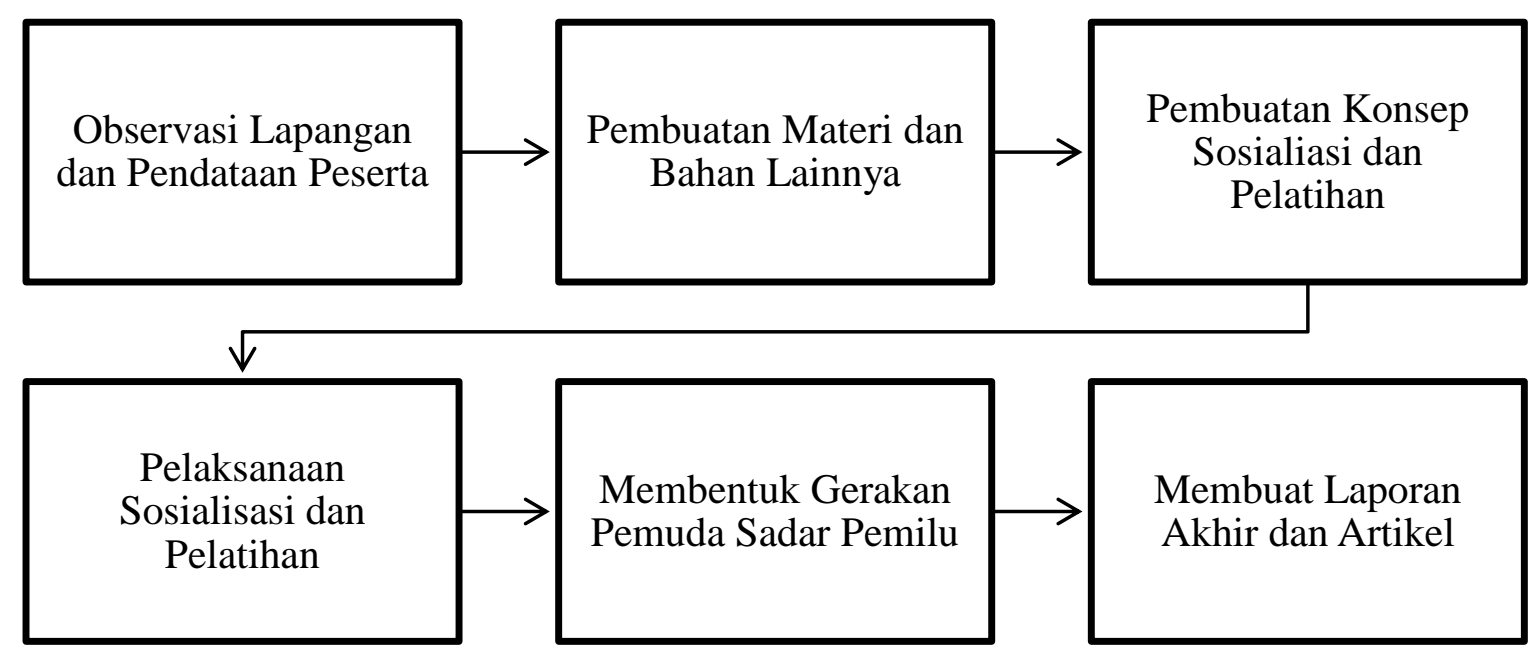

PEMBASAHAN

Pemilu pada prinsipnya merupakan mekanisme penyaluran pendapat rakyat secara berkala. Bagi negara demokrasi penyelenggaraan pemilu dapat dipandang sebagai awal 
dari paradigma demokrasi (Suewoto, 1990). Pemilu pada prinsipnya adalah wujud penyaluran kedaulatan rakyat secara langsung. Karena pemilihan umum diselenggarakan bertujuan: (1) untuk memungkinkan terjadinya peralihan kepemimpinan pemerintahan secara tertib dan damai, (2) untuk memungkinkan terjadinya penggantian pejabat yang akan mewakili kepentingan rakyat di lembaga perwakilan, (3) untuk melaksanakan prinsip kedaulatan rakyat, dan (4) untuk melaksanakan prinsip hak-hak asasi warga negara (Asshiddiqie, 2006).

Dari data yang didapatkan, KPU Kota Banjarmasin menetapkan ada 423.392 jumlah pemilih untuk 1.870 Tempat Pemungutan Suara (TPS) seBanjarmasin. Jumlahnya adalah 208.942 pemilih laki-laki dan 214.450 pemilih perempuan dengan total keseluruhannya sebanyak 423.392 pemilih yang masuk dalam Daftar Pemilih Tetap (DPT) untuk bisa mengikuti Pemilu 2019 mendatang. Rinciannya, Kecamatan Banjarmasin Selatan terdiri 12 Kelurahan untuk 444 TPS dengan jumlah pemilih 51.926 pemilih laki-laki dan 52.197 pemilih perempuan. Banjarmasin Utara terdiri dari 10 Kelurahan untuk 395 TPS, dengan jumlah pemilih 45.444 pemilih laki-laki dan 46.539 pemilih perempuan. Kecamatan Banjarmasin Barat ada sembilan kelurahan untuk 397 TPS, terdiri dari 43.751 pemilih lakilaki dan 44.569 pemilih perempuan. Kecamatan Banjarmasin Timur untuk sembilan kelurahan teridir 358 TPS dengan jumlah pemilih 37.768 pemilih laki-laki dan 39.810 pemilih perempuan. Kecamatan Banjarmasin Tengah ada 12 kelurahan terdiri dari 276 TPS, untuk 30.053 pemilih laki-laki dan 61.388 pemilih perempuan (http://banjarmasin.tribunnews.com/201 8/08/21/kpu-banjarmasin-tetapkan-dptpemilu-2019-ini-rinciannya, diakses pada 28 September 2018).

Kementerian Dalam Negeri (Kemendagri) mencatat ada 5.035.887 orang pemilih pemula pada Pemilu 2019. Data ini masuk dalam Daftar Penduduk Pemilih Potensial Pemilu (DP4).

(https://news.detik.com/berita/4215354/ ada-5-juta-pemilih-pemula-di-pemilu2019, diakses pada 28 September 2018). Dari data pilkada Kota Banjarmasin pada Tahun 2015 yang lalu, data pemilih pemula mencapai 40 Persen dari jumlah DPT (http://banjarmasin.tribunnews.com/201 
5/08/26/di-banjarmasin-40-persenpemilih-pemula, diakses pada 28 September 2018)

Pelaksanaan kegiatan pengabdian masyarakat bertajuk Sosialisasi Pemilu Kepada Pemuda Guna Menciptakan Pemuda Yang Sadar Pemilu Di Kota Banjarmasin telah dilaksanakan sesuai dengan metode yang telah ditetapkan. Sebagaimana yang dijelaskan pada bagian sebelumnya, partisipasi adalah hal penting dalam setiap pemilu. Partisipasi bukan saja mengikuti pemilu di bilik suara, tetapi juga ikut berperan aktif dalam setiap tahapan pemilu termasuk mengkampanyekan nilai-nilai postitif dalam pemilu seperti ajak untuk memilih/tidak golput. Pengabdian masyarakat ini juga menuai hasil sebagaimana yang di inginkan. Setelah mengikuti kegiatan, para pemuda turut aktif mensosialiasikan pemilu yang jujur dan adil seperti menggelar diskusi dan membentuk gerakan pemuda sadar pemilu.

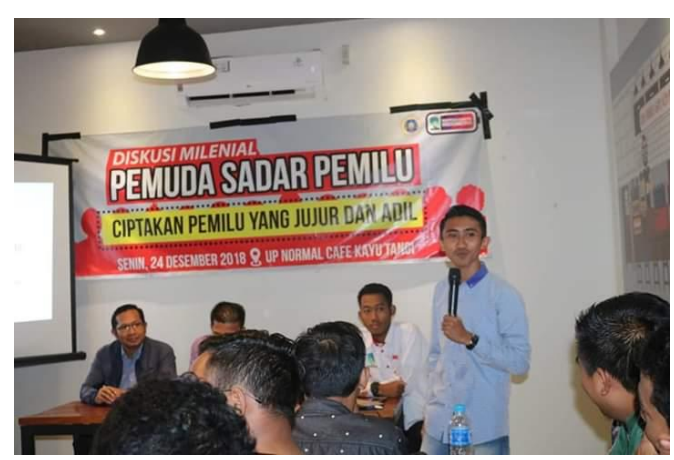

Foto 1: Kegiatan pemaparan materi oleh narasumber

Tempat: “ Warung Upnormal” Jalan

Brigjen Hasan Basri- Kayu Tangi

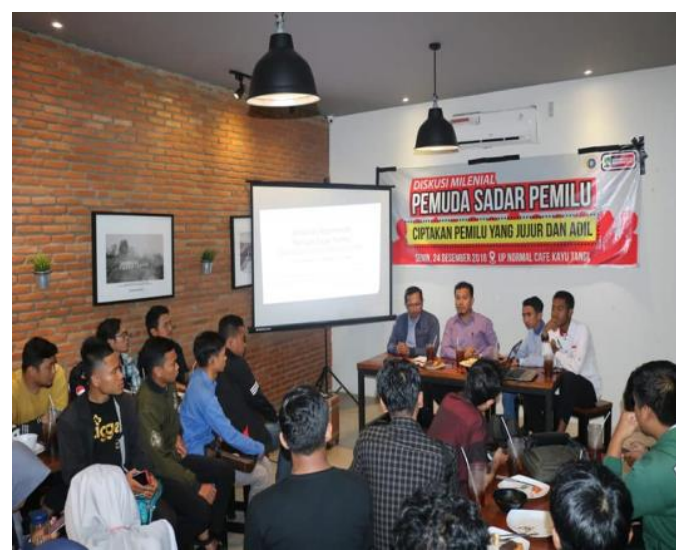

Foto 2: Kegiatan diskusi dan tanya jawab

Tempat: “ Warung Upnormal” Jalan Brigjen Hasan Basri- Kayu Tangi

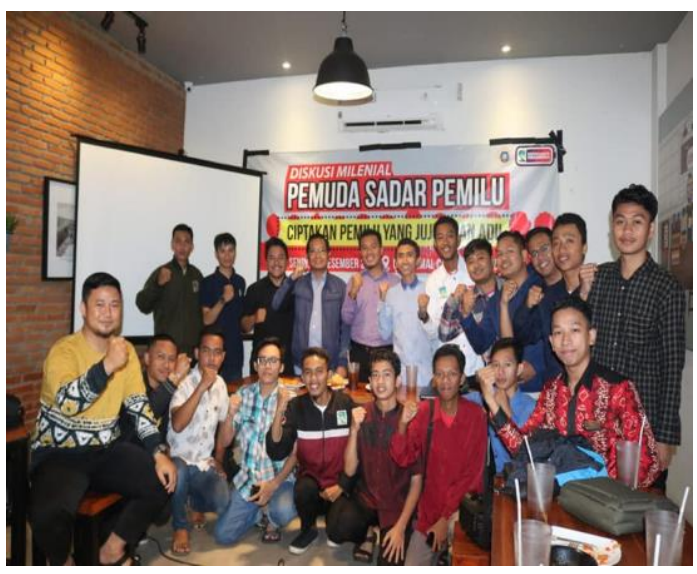

Foto 3: Kegiatan pernyataan komitmen bersama untuk mengawal pemilu dan menggunakan hak pilih dengan jujur dan adil Tempat: “Warung Upnormal” Jalan Brigjen Hasan Basri- Kayu Tangi 


\section{KESIMPULAN}

Kesimpulan dari kegiatan ini adalah, pertama partisipasi pemilih pemula sangat penting dalam pelaksanaan pemilu, oleh sebab itu perlu upaya untuk meningkatkan partisipasi pemilih pemula tersebut. Salah satu cara dalam meningkatkan hal tersebut adalah dengan sosialisasi mengenai pemilu yang ditujukan kepada pemilih pemula. Kedua, metode yang digunakan untuk sosialisasi kepada pemilih pemula mesti harus menyesuaikan dengan kondisi mereka. Salah satu yang digunakan dalam pengabdian ini adalah dengan diskusi santai dengan pemilih pemula di nuasa yang tidak formal tetapi memiliki makna. Adapun saran dari hasil kegiatan ini yaitu pertama, diperlukan keterlibatan perguruan tinggi secara terus menerus dalam rangka mengawal partisipasi pemilih pemula dalam pemilu. Kedua, diperlukan penelitian lebih lanjut tentang metode dalam pelibatan pemilih pemula dalam pelaksanaan pemilu.

\section{DAFTAR PUSTAKA}

Soewoto, Kekuasaan dan Tanggung jawab Presiden Republik Indonesia (Suatu Penelitian SegiSegi Teoritik dan Yuridik Pertanggungjawaban Kekuasaan), (Disertasi: Universitas Airlangga), Surabaya, 1990

Jimly Asshiddiqie, Konstitusi dan Konstitusionalisme Indonesia, (Jakarta : Setjen Mahkamah Konstitusi republik Indonesia, 2006)

http://banjarmasin.tribunnews.com/2018 /08/21/kpu-banjarmasin-tetapkandpt-pemilu-2019-ini-rinciannya, diakses pada 28 September 2018

https://news.detik.com/berita/4215354/a da-5-juta-pemilih-pemula-dipemilu-2019, diakses pada 28 September 2018

http://banjarmasin.tribunnews.com/2015 /08/26/di-banjarmasin-40-persenpemilih-pemula, diakses pada 28 September 2018

https://www.kammi.or.id/, diakses pada 28 September 2018 